\title{
EDITORIAL: THE DIVERSITY OF INTERNATIONAL ICT LAW
}

by

\section{DAN JERKER B. SVANTESSON}

The Masaryk University Journal of Law and Technology (MUJLT) was established in 2007 and is now in its ninth year. All along it has had a strong international focus. This is of course only natural given that ICT law, by its very nature, is a strongly international discipline. After all, the Internet is a near global communications network and most of our activities online have some form of international dimension.

Another reason for the Journal's international focus is found in the fact that a considerable proportion of the articles published represent the fruit of the highly successful conference on interdisciplinary cyberspace issues held annually at the Masaryk University. I have attended this conference every year since 2004 and have witnessed it grow and truly blossom under the diligent leadership of Radim Polčák.

This Special Issue of the MUJLT focuses specifically on international ICT law issues, and is aimed at showcasing the diversity of matters that arise in the cross-section of law, technology and the international dimension. All the contributions included are based on presentations given at Cyberspace 2014 held at Masaryk University 28-29 November 2014 and cover a wide range of ICT law issues that all, in one way or another, have an international dimension.

Three contributions deal with the European Union's reform of its approach to consumer protection issues, including cross-border consumer issues. Michael Bogdan (Lund University) addresses in his comment the new EU Regulation No 524/2013 on Online Dispute Resolution for

Professor and Co-Director, Centre for Commercial Law, Faculty of Law, Bond University (Australia). Researcher, Swedish Law \& Informatics Research Institute, Stockholm University (Sweden). 
Consumer Disputes, which will apply from 9 January 2016. The article by Anabela Susana de Sousa Gonçalves (University of Minho) examines the difficulties of applying Article 6 of the Rome I Regulation to e-commerce and discusses the interpretative options of the European Union Court of Justice. And Agata Jaroszek (University of Wrocław) discusses the rationale of protecting consumers under the new Directive on consumer rights and its relation to conflict of laws rules under the Rome I Regulation as applicable to contractual obligations.

The article by Anna-Maria Osula (NATO Cooperative Cyber Defense Centre of Excellence and Tallinn University of Technology) tackles the complexities associated with, and the role of, Mutual Legal Assistance and other established mechanisms of international cooperation in the fight against cyber crime. Martin Sramek (European Information Society Institute) focuses his comment on the decision Pinckney vs. KDG Mediatech AG and the shift from the traditional interpretation of special jurisdiction provisions, and the contribution by Coleen Lewis (The University of the West Indies at Mona) deals with defamation in social media from the perspective of the Jamaican Defamation Act 2013. The paper by Jan Tomisek (Rowan Legal) evaluates and compares the contracts for the provision of Google Apps for Work and Microsoft Office 365 for small and medium enterprises from the perspective of the requirements of European data protection law as regards the contents of a contract between cloud provider and cloud client. In his contribution, Pavel Loutocký (Masaryk University) focuses on the question whether we are getting good decisions from ICANN's uniform domain name dispute resolution policy. The last article summarises the arguments I presented in my Keynote at Cyberspace 2014 addressing the uncertain future of data privacy law with a particular emphasis on its international dimensions.

This Special Issue is a product of the longstanding, and ongoing fruitful collaboration between the Institute of Law and Technology, Faculty of Law at Masaryk University and the Centre for Commercial Law, Faculty of Law at Bond University (Australia). More specifically, the Special Issue represents one component in a four-year research project (2012-2016) on jurisdiction in the Internet era of cloud computing, Web 2.0 and geolocation technologies funded by the Australian Research Council. That project - an Australian Research Council Future Fellowship - reassesses and re-evaluates how the concept of jurisdiction most appropriately can be 
applied in the Internet era characterised by cloud computing, Web 2.0 and geo-location technologies. In doing so, the project identifies a set of core principles to govern jurisdictional claims over Internet conduct and produces a set of detailed model laws.

I want to take this opportunity to thank the Australian Research Council for their support for the project. I also want to thank the editorial team of the MUJLT and the organisers of Cyberspace 2014. Finally, I want to thank the real heroes - the authors of the excellent papers that appear in this Special Issue.

I have sincerely enjoyed working on this Special Issue of the MUJLT and I hope you, the reader, will enjoy the articles contained in it.

Dan Jerker B. Svantessson 18 March 2015, Gold Coast Australia 